\title{
Pemberlakuan Kurikulum Berbasis Nilai dan Karakter dalam Pembelajaran Pendidikan Agama Kristen Terhadap Kecerdasan Spiritual Siswa SMA Negeri Di Tana Toraja.
}

\author{
Syani Bombongan Rante Salu \\ Institut Agama Kristen Negeri Toraja \\ syani_rantesalu@yahoo.co.id
}

DOI: https://doi.org/10.34307/b.v3i2.152

\begin{abstract}
A value and character based curriculum is the core of the curriculum from time to time which is designed to answer the challenges of the times. In this paper, the author wants to examine the application of value-based and characterbased curriculum in Christian Religious Education learning to the spiritual intelligence of public high school students in Tana Toraja. This is considered important because in the implementation of a value-based and character-based curriculum it has less impact on the spiritual intelligence of state high school students in Tana Toraja. The method used in this paper is qualitative research with descriptive analysis method. This study concludes that the curriculum developed in Christian religious education learning is still general in nature, which is designed in general in a universal context which is then developed according to a particular context. The curriculum in the context of Christianity in learning values and character in Christian education is only one source, namely from the Bible and applies to everyone in all places, as for the value in character building in relation to this spiritual intelligence, namely the value of love which is the main command of God, readiness to hear. and slow to speak, the value of holiness is not defiling oneself with various temptations and the values of the fruit of the Holy Spirit, namely love, joy, peace, patience, generosity, kindness, loyalty, gentleness and selfcontrol.
\end{abstract}

Keywords: values, character, spiritual intelligence

Abstrak: Kurikulum berbasis nilai dan karakter adalah inti dari dari kurikulum dari masa ke masa yang di desain untuk menjawab tantangan jaman. Dalam tulisan ini, penulis ingin mengkaji pemberlakuan kurikulum berbasis nilai dan karakter dalam pembelajaran Pendidikan Agama Kristen terhadap Kecerdasan spiritual siswa SMA Negeri di Tana Toraja. Hal ini dianggap penting oleh karena dalam pemberlakuan kurikulum berbasis nilai dan karakter kurang berdampak bagi kecerdasan spiritual siswa SMA Negeri di Tana Toraja. Dalam tulisan ini menggunakan metode kualitatif dengan analisis dekriptif. Penelitian ini menyimpulkan bahwa, kurikulum yang dikembangkan dalam pembelajaran pendidikan Agama kristen masih bersifat umum, yakni dirancang secara umum dalam konteks universal yang kemudian dikembangkan sesuai konteks tertentu. Kurikulum dalam konteks kekristenan dalam pembelajaran nilai dan karakter pada pendidikan Kristen hanya satu sumber yakni dari Alkitab dan berlaku bagi setiap orang disegala tempat, adapun nilai dalam pembentukan karakter dalam kaitannya dengan kecerdasan spiritual ini yakni nilai kasih yang merupakan perintah utama Tuhan Allah, kesiapan untuk mendengar dan lambat untuk 
berkata-kata, nilai kekudusan yakni tidak menajiskan diri dengan berbagai godaan jasmani dan nilai-nilai dari buah Roh Kudus

Kata Kunci: Nilai, karakter, kecerdasan spiritual

\begin{tabular}{llll}
\hline Article History : & Received: 26-03-2020 & Revised: 16-09-2020 & Accepted:03-12-2020
\end{tabular}

\section{PENDAHULUAN}

Perkembangan kurikulum pendidikan dari masa ke masa senantiasa berubah mengikuti aturan perundang-undangan dan untuk menjawab tantangan dan kebutuhan kemajuan global. Pada dasarnya, kurikulum yang dikembangkan mengacu kepada pendidikan nilai dan pembentukan serta pengembangan karakter peserta didik yang kemudian dibungkus dalam berbagai tehnik sehingga dapat efektif dalam mencapai tujuan pendidikan yang sesungguhnya. Jika kembali melihat sejarah perkembangan kurikulum di Indonesia maka ditemukan bahwa ada dua masa yakni masa sebelum kemerdekaan dan masa sesudah kemerdekaan. Adapun masa kemerdekaan yakni pada masa penjajahan Belanda dan Jepang dengan muatan yakni untuk penyebaran agama untuk mempermudah perdagangan. Namun dari pandangan bangsa Indonesia kurikulum bermuatan untuk keruntuhan penjajahan. Adapun muatan kurikulum setelah kemerdekaan yakni dimulai pada kurikulum 1947 yang berisi muatan mengenai perkembangan karakter, kecintaan terhadap Negara melebihi pendidikan yang berorientasi pada kognitif, kurikulum tahun 1952 memiliki ciri khusus yakni desain pembelajaran berfokus pada pembelajaran yang berorientasi pada aktivitas keseharian anak, kurikulum 1964 memiliki kekhususan yakni mengacu dan berfokus pada pengembangan daya cipta, rasa, karsa, karya, dan moral, kurikulum 1968 berisi muatan pada penekanan pada pada pengamalan pancasila serta mempertinggi kecerdasan dan keterampilan jasmani, moralitas, budi pekerti, dan penguatan keagamaan. Kurikulum 1975 lebih menekankan pada pendidikan yang semakin efektif dan efisien. Kurikulum 1984 berisi muatan mengusung process skill approach, kurikulum 1994 menekankan tujuan dari proses pembelajaran pada bagaimana seorang peserta didik memahami konsep-konsep yang diberikan dan mampu menyelesaikan masalah dengan mengacu dan berpedoman pada konsep yang telah diberikan, pada kurikulum 2004 berisi muatan Pendidikan berbasis kompetensi menitikberatkan pada pengembangan kemampuan untuk melakukan (kompetensi), kurikulum 2006 berisi muatan pendidikan karakter bangsa yang berorientasi pada pengembangan daerah, selanjutnya kurikulum 2013 yang bersifat tematik dan integrative dengan muatan empat kompetensi inti yakni 
hubungan dengan Tuhan, hubungan dengan sesame, kognitif dan psikomotor." ${ }^{1}$ Melihat perkembangan kurikulum ini, sesungguhnya kurikulum yang dibuat oleh pemerintah senantiasa terus berkembang dan semakin baik dari masa ke masa.

Dalam Pendidikan Agama Kristen, juga senantiasa mengikuti perkembangan kurikulum dari pemerintah dengan tidak mengabaikan dasar kurikulum dari Alkitab yakni pendidikan nilai dan karakter. Rusman mengatakan, "Standar kompetensi dalam suatu Kelompok satuan mata pelajaran Agama adalah"1. Memiliki perilaku yang sesuai dengan ajaran agama yang dianut yang kemudian disesuaikan dengan perkembangan anak remaja. 2. Berpartisipasi untuk terlibat dalampelaksanaan dan penegakan aturan social yang berlaku. 3. Mampu memahami keseimbangan antara hak dan kewajiban diri sendiri maupun orang lain dalam kaitannya dengan pergaulan di dalam masyarakat. 4 . Menghargai setiap perbedaan pendapat dan memiliki rasa empati yang tinggi terhadap orang lain. 5. Mengadakan komunikasi dan interaksi secara efektif dan tetap pada sikap yang sesuai yang dilakukan melalui berbagai macam cara, tidak terkecuali dalam kaitannya dengan pemanfaatan teknologi dan informasi yang kemudian mencerminkan harkat dan martabatnya sebagai makhluk yang diciptakan oleh Tuhan. 6. Mampu menjaga lingkungan sebagai rasa tanggung jawab makhluk ciptaan Tuhan." ${ }^{2}$ Membandingkan kurikulum dari masa kemasa maka hal yang tidak dapat dilupakan dalam suatu kurikulum adalah muatan nilai dan karakter yang dapat membentuk nara didik cerdas secara spiritual. Kecerdasan spiritual adalah dasar dari segala kecerdasan bagi setiap orang untuk mampu menghadapi berbagai tantangan zaman, $\mathrm{n}$ kecerdasan spiritual juga dapat menjadikan peserta didik dapat melihat sesuatu yang lebih baik, meraih kegembiraan dan mempunyai kegigihan dalam menghadapi kehidupan. ${ }^{3}$

Kecerdasan spiritual adalah tujuan utama dari Kurikulum berbasis nilai dan karakter pada pendidikan agama kristen. Kecerdasan spiritual merupakan suatu tindakan yang mampu menghadapi terlebih menyelesaikan persoalan yang berkaitan dengan makna dan nilai, yakni yang berhubungan dengan sesama manusia dan dunia sekitar dalam hubungannya dengan Tuhan. Atau dengan kata lain, kecerdasan spiritual adalah kemampuan dari diri untuk memberi makna teologis pada setiap tindakan, sehingga tujuannya hanya kepada Allah. Kecerdasan spiritual menggali kemampuan dalam diri yang kemudian dikembangkan melalui institusi pendidikan dan tentunya potensi itu harus dilatih dan dikembangkan secara sistematis yang melibatkan banyak oknum dalam lingkup pendidikan misalnya kurikulum, guru, dan lingkungan.

1Fitri Wahyuni, Kurikulum Dari Masa ke Masa (Telaah Atas Pentahapan Kurikulum Pendidikan Di Indonesia), (Al-Adabiah: Jurnal Kebudayaan dan Keagamaan: vol 10 no 2 tahun 2015), 233-237.

${ }^{2}$ Rusman, Managemen Kurikulum (Seri managemen sekolah bermutu) (Jakarta: PT Raja grafindo Persada, 2009), 437.

${ }^{3}$ Santy Sahartian, Pemahaman Guru Pendidikan Agama Kristen Tentang II Timotius 3:10 Terhadap Peningkatan Kecerdasan Spiritual Anak Didik (JURNAL FIDEI Vol.1 No.2 (December 2018): ISSN: 26218151(Print) ISSN: 2621-8135(online), 146-172. 
Kecerdasan spiritual sangat penting bagi anak oleh karena melihat tantangan masa kini yang semakin rumit dimana hal ini tidak mungkin hanya dapat dilalui dengan mengandalkan skill intelektual (IQ) maupun kecerdasan emosi (EQ), tetapi sangat membutuh dukungan kecerdasan spiritual (SQ) hal ini penting melihat Kecerdasan spiritual mampu menjawab tantangan dunia sekarang. Seseorang yang memiliki kecerdasan spiritual memiliki integritas dan selalu melakukan kehendak Tuhan. Orang yang memiliki kecerdasan spiritual takut akan Tuhan sehingga ia tidak mau melakukan apa yang tidak dikehendaki oleh Tuhan. Dia juga dekat dengan Tuhan maka ia mengandalkan Tuhan di dalam setiap perkara. Kecerdasan spiritual merupakan inti dari semua kecerdasan. Alkitab menyatakan bahwa, "Takut akan Tuhan adalah permulaan hikmat dan pengetahuan" (Ams. 1:7). Kekeringan rohani dapat menjadi salah satu indikator pada ketidakcerdasan dalam hal spiritualitas.

Dari pengamatan penulis terhadap 3 sekolah negeri tingkat SMA yang ada di Tana Toraja, perencanaan pembelajaran dan pelaksanaan pembelajaran yang berbasis nilai dan karakter dan telah dilaksanakan dengan baik, namun pada kenyataannya masih ada saja siswa yang tidak mendapatkan dampak dari pemberlakuan kurikulum tersebut, ditunjukkan dengan sikap tidak mencerminkan peserta didik yang memiliki kecerdasan spiritual. Salah satu indikator kecerdasan spiritual adalah sikap jujur orang yang memiliki kecerdasan spiritual tentunya tidak akan suka berbohong dan bertindak tidak jujur. Banyaknya anak rela berbohong dan membuat suart sakit palsu ketika terlambat untuk tidak mendapatkan pengurangan poin. ${ }^{4}$ Sikap jujur tentunya harus diaplikasikan dalam tindakan setiap hari sebagai implementasi takut akan Tuhan yang juga merupakan dasar dari kecerdasan Spiritual.

Penelitian terdahulu sekaitan dengan pendidikan nilai dan karakter yakni Pengutamaan Dimensi Karakter Dalam Pendidikan Agama Kristen oleh Daniel Nuhamara, dalam tulisan ini penulis menguraikan kaitan pendidikan karakter dengan Pendidikan Agama Kristen, dalam hal ini penulis menguraikan bahwa Pendidikan Agama Kristen adalah hal pokok dari iman kristiani dalam hal ini penulis menitik beratkan pada prinsip alkitabiah, nilai kebajikan, makna hidup serta karakter. Oleh penulis hal inilah yang dapat dilakukan untuk membangun karakter Kristiani yang unggul. ${ }^{5}$ B. S Sidjabat membahas Kerangka Kurikulum Pendidikan Agama Kristen Berbasis Karakter di Perguruan Tinggi. Dalam tulisan ini menjelaskan konsep pendidikan karakter menurut iman Kristen, bagaimana pendidikan karakter dalam kurikulum perguruan tinggi, dan kerangka kurikulum PAK di perguruan tinggi umum. Kemudian penulis menawarkan sebuah kerangka kurikulum PAK mengakomodasi

${ }^{4}$ Tabita, wawancara penulis (Makale 20 Februari 2020)

${ }^{5}$ Daniel Nuhamara, "Pengutamaan Dimensi Karakter Dalam Pendidikan Agama Kristen, (Jurnal Jaffray 16, no. 1 (2018): 93. 
pendidikan karakter ${ }^{6}$ Rifai membahas pendidikan karakter bagi remaja dalam konteks pendidikan Kristen di sekolah menengah, kajian ini memberikan kesimpulan bahwa pembentukan karakter adalah faktor utama kesuksesan pendidikan Agama Kristen sehingga pelaku pendidik yakni guru dan orang tua perlu meminta pertolongan kepada Tuhan dalam doa dan penyerahan sepenuhnya kepada Roh kudus dan hal penting lainnya yakni sekolah perlu menggunakan system evaluasi yang efektif. ${ }^{7}$

Dalam tulisan ini, penulis melihat dan menilai muatan kurikulum dari masa ke yang intinya memuat nilai-nilai dan karakter hingga kurikulum yang terakhir yakni kurikulum 2013 yang memuat empat kompetensi yakni hubungannya dengan Tuhan, sesama, menyangkut kognitif dan psikomotor kurang berdampak, sehingga muncul pertanyaan sejauhmana kurikulum berbasis nilai dan karakter dalam pembelajaran Pendidikan Kristen berpengaruh terhadap kecerdasan spiritual siswa SMA Negeri di Tana Toraja? Kemudian penulis menawarkan muatan pendidikan nilai dan karakter pada konteks kekristenan dalam kaitannya dengan kecerdasan spiritual sebagai dasar dari semua kecerdasan dalam menjawab tantangan jaman yang berasal dari satu sumber dan berlaku secara universal bagi semua pelaku pendidikan Kristen disegala tempat.

\section{METODE PENELITIAN}

Dalam penelitian ini, penulis menggunakan penelitian kualitatif dengan metode deskriptif analisis yakni dengan studi pustaka mengenai nilai karakter dalam kaitannya dengan kecerdasan spiritual dalam konteks Pendidikan Kristen, adapun hasil penelusuran pustaka dianalisis sesuai dengan keadaan di lapangan yang kemudian memberikan suatu pemahaman baru bagaimana konsep pendidikan Kristen tentang nilai dan karakter dapat memberi suatu pengaruh dalam pembelajaran anak untuk meningkatkan kecerdasan spiritual siswa SMA Negeri di Tana Toraja.

\section{HASIL DAN PEMBAHASAN}

\section{Nilai dan Karakter dalam Pembelajaran Pendidikan Kristen}

Nilai adalah hal yang bermanfaat atau penting untuk kemanusiaan." 8 Value atau nilai adalah sifat/ciri khas yang membuat halnya pantas dikagumi, dihargai. Nilai atau value adalah suatu ukuran yang menjadi pedoman setiap orang yang mana hal inilah yang mempengaruhi orang tersebut dalam bertindak dan bertingkahlaku. nilai-nilai hidup diyaniki akan ampak pada setiap tingkahlaku individu. Nilai pada umumnya dapat diartikan dalam dua pengertian yakni segala sesuatu yang dijadikan sebagai standar

\footnotetext{
${ }^{6}$ Binsen Samuel Sidjabat, "Kerangka Kurikulum Pendidikan Agama Kristen Berbasis Karakter Di Perguruan Tinggi Character-Based Christian Religious Education Curriculum Framework in Higher Education, (Jurnal Jaffray 17, no. 1 (2019): 73-90.

${ }^{7}$ Rifai, "Pendidikan Kristen Dalam Membangun Karakter Remaja Di Sekolah Menengah, (AntusiasJurnal Teologi dan Pelayanan 2, no. 2 (2012): 1-17.

${ }^{8}$ Salim dan Salim, Kamus Besar Bahasa Indonesia (Jakarta: Modern English), s.v "nilai".
} 
untuk pengambilan keputusan dan kedua yakni segala sesuatu yang diakui dan dianggap memiliki nilai. Dalam kedua pengertian ini, nilai dapat tangible yakni memiliki bentuk seperti dan juga intangible yakni tidak berwujud seperti tradisi, ada istiadat, kebiasaan, moralital, norma, estetika, harga diri, kepercayaan, disiplin, gagasan, ilmu pengetahuan dan lain sebagainya." 9 Selanjutnya pendidikan Karakter berkaitan dengan watak, akhlak, tabiat, ataupun kepribadian yang dimiliki oleh seseorang yang diyakini dan digunakan sebagai landasan dalam kehidupan sebagai cara pandang, bersikap, berpikir, maupun bertindak. "10 pendidikan karakter mengacu kepada suatu tindakan nyata yang sistematis dan terencana untuk mempersiapkan generasi unggul dimasa yang akan datang, yang tidak melupakan nilai-nilai luhur yang terkandung dalam masyarakat. Pendidikan karakter secara khusus dalam lingkup sekolah memiliki visi yakni menjadikan manusia yang integral yakni dengan pemahaman tujuan pendidikan yang visioner dan pemahaman tentang nilai-nilai yang berlaku universal."11 Dalam proses pendidikan, setidaknya ada empat karakter yang dikenal dan dikembangkan yakni pertama pendidikan karakter berbasis nilai religius yang berdasarkan kebenaran wahyu Tuhan dengan titik pada moralitas, kedua, pendidikan karakter berbasis nilai budaya yakni yang berupa budi pekerti, pancasila, apresiasi budaya, ketiga, pendidikan karakter berbasis lingkungan dan keempat pendidikan karakter yang berbasis potensi diri yakni sikap pribadi yang diberdayakan untuk tujuan pendidikan."12 Pembangunan karakter dapat terjadi dengan tatanan kehidupan berbangsa dan bertanah air yang baik dan benar. Pancasila adalah sumber karakter bangsa Indonesia. Character building disini dapat diatikan sebagai tatanan hidup harus menampakkan karakter berbasis nilai-nilai luhur Pancasila yang cerdas dan berdaya saing tinggi. Pendidikan karakter dalam pembangunan bangsa, berarti memfokuskan seluruh kehidupan yang berbasis nilai-nilai pancasila. Di sinilah peran pendidikan karakter untuk pembangunan bangsa, agar seluruh warga negara secara khusus begara Indonesia tetap berfokus dan memiliki karakter bangsa yang terpancar dalam kehidupan nyata seseorang. Hal ini lebih tepatnya terlaksana mulai dari dunia pendidikan sebagai agen perubahan bangsa. Pendidikan karakter berisi muatan tentang baik dan buruknya suatu keadaan dan lebih dari itu berisi penanaman dan pembiasaan kesadaran dan pemahaman yang tinggi serta kepedulian yang sungguh dan komitmen untuk menetapkan kebajikan dalam kehidupan sehari-hari. ${ }^{13}$ Dalam pendidikan karakter pemahaman tentang nilai universal sangat penting yang kemudian hal ini diimplementasikan dalam dunia pendidikan.

\footnotetext{
${ }^{9}$ St. Sularto, Masyarakat Warga dan Pergulatan Demokrasi (Jakarta: Pustaka Nasional, 2001), 56.

${ }^{10}$ Said Hamid Hasan dkk. Pengembangan Pendidikan Budaya dan Karakter Bangsa (Jakarta: Kemdiknas Badan Penelitian dan Pengembangan Pusat kurikulum, 2010), 2-4.

${ }^{11}$ Doni Koesema, Pendidikan Karakter (strategi mendidik anak di zaman global) (Jakarta: GRASINDO, 2007), 8.

${ }^{12}$ Adi Suprayitno, Pendidikan Karakter di era minenial (Yogyakarta: Deepublish, 2020), 57.

${ }^{13}$ Cut Zahri Harun, Manajemen Pendidikan Karakter
} 
Pendidikan karakter tidak terlepas dari nilai dari tiap-tiap agama. Masyarakat Indonesia memiliki dasar Negara yakni pancasila dimana sila pertama menekankan tentang keTuhanan yang maha esa, setiap tatanan kehidupan masyarakat bangsa Indonesia senantiasa berlandaskan ajaran agama setiap orang, dalam berpolitik, dalam berbudaya maupun dalam keseharian kehidupan seseorang berlandaskan pada ajaran agama. Dalam agama Kristen, nilai-nilai kristiani bersumber dari Firman Allah. Nilainilai agama secara khusus nilai agama kristen yang terintegrasi dalam nilai-nilai Kristiani adalah pengamalan iman yang diwujud nyatakan dalaam setiap tingkahlaku kehidupan seseorang. Dari pemaparan ini dapat disimpulkan bahwa Komponen pendidikan karakter, berpatokan pada pancasila yang tidak terlepas dari nilai-nilai agama yang terintegrasi dalam dunia pendidikan. Nilai-nilai karakter yang terkandung dalam Kurikulum Pendidikan Agama Kristen adalah berdasarkan kasih agape, kasih yang suci dan tanpa pamrih menjadi dasar orang Kristen melaksanakan nilai krsiten yang seseungguhnya, kasih agape yang telah dinyatakan oleh Tuhan Yesus kemudian menjiwai setiap orang Kristen untuk melakukan nilai-nilai yang baik dan benar sesuai ajaran agama Kristen.

Dalam kekristenan salah satu nilai dan pendidikan karakter yang sangat penting untuk dikembangkan adalah sikap lambat berkata-kata dan giat dalam mendengar. Pendidikan Kristiani menghadirkan suatu unsur dalam pengajaran yakni mendengar, hal ini penting dalam mencapai tujuan proses belajar Pendidikan Kristiani, baik yang dilaksanakan di sekolah, gereja, dan di dalam keluarga ${ }^{14}$ Tokoh alkitab yakni Daniel menunjukkan nilai kristiani dalam segi kehidupannya dengan tidak menajiskan diri dari godaan jasmani secara khusus makanan (Dan 1:8), disiplin rohani yakni kehidupan doa yang terus menerus dilakukan sebagai suatu kebiasaan dan gaya hidupnya. ${ }^{15}$ Selanjutnya nilai kristiani yang penting untuk dikembangkan dalam pendidikan di keluarga yakni pengimplementasian buah-buah Roh Kudus dalam Galatia 5: 22-2316

Kurikulum pendidikan secara umum dalam kaitannya dengan pendidikan nilai dan karakter dibuat secara integral berdasarkan Pancasila dan kebutuhan tuntutan jaman, kemudian dipahami dan dikontekskan oleh pelaku pendidikan sesuai dengan keadaan, social, budaya, lingkungan, norma dan kebiasaan yang berlaku di tempat tertentu dengan demikian pendidikan nilai dan karakter yang dikembangkan dapat berbeda satu dengan yang lainnya, dan hal inipun yang dikembangkan dalam pembelajaran di SMA Negeri di Tana Toraja. Dalam Kurikulum pendidikan Kristen

\footnotetext{
${ }^{14}$ Harls Evan Rianto Siahaan, "Hikmat Sebagai Implikasi Pendidikan Kristiani: Refleksi 1 Raja-Raja 3:1-15," (DUNAMIS: Jurnal Penelitian Teologi dan Pendidikan Kristiani 1, no. 1 (2016): )15.

${ }^{15}$ Agustin Soewitomo Putri, "Menstimulasi Kualitas Kehidupan Rohani Dalam Meningkatkan Kemandirian Belajar Mahasiswa: Studi Refleksi Daniel 6:1-4, (DUNAMIS: Jurnal Penelitian Teologi dan Pendidikan Kristiani 1, no. 2 (2017): 156.

${ }^{16}$ May Rauli Simamora dkk, Penanaman Nilai-Nilai Kristiani Bagi Ketahanan Keluarga Di Era Disrupsi (Regula Fidei: Jurnal Pendidikan Agama Kristen Volume 5, Nomor 1, Maret 2020), 23.
} 
bersumber dari satu sumber yakni alkitab dan berlaku secara umum bagi setiap orang disegala tempat, adapun nilai dalam pembentukan karakter dalam kaitannya dengan kecerdasan spiritual ini yakni nilai kasih yang merupakan perintah utama Tuhan Allah, kesiapan untuk mendengar dan lambat untuk berkata-kata, nilai kekudusan yakni tidak menajiskan diri dengan berbagai godaan jasmani dan nilai-nilai dari buah Roh Kudus yakni kasih, sukacita, damai sejahtera, kesabaran, kemurahaan, kebaikan, kesetiaan, kelemah lembutan dan penguasaan diri.

\section{Kecerdasan Spiritual}

Cerdas berarti sempurna perkembangan akal budinya untuk berpikir; tajam pikiran, sempurna pertumbuhan tubuhnya. ${ }^{17}$ Cerdas menyangkut segala aspek diri yakni jasmani dan intelektual. Kecerdasan memungkinkan seseorang untuk bertindak, dan mengamalkan ajaran agama tidak hanya pada satu titik saja. Kecerdasan tidak membuat setiap individu hanya mampu mengetahui sesuatu kebenaran, namun individu yang cerdas akan mampu mengaktualisasikan kebenarana yang telah diketahuinya dalam tindakan nyata, sehingga tindakan itu akan membentuk watak pribadi yang baik dan benar. Sedangkan spiritual oleh Barbara E. Bowe seperti yang dikutip oleh Ismael Banne Ringgi mengatakan, Secara etimologis, kata 'spiritual' diambil dari bahasa Latin, spare, yang berarti menghembus, meniup, mengalir. Dari kata spare muncul kata benda spiritus, yang berarti nafas (breath), kehidupan (life), roh (spirit). ${ }^{18}$ Spiritual berarti yang berhubungan dengan atau dapat diartikan bersifat kejiwaan (rohani, batin)."19 Lanjut Budi Yuwono mengatakan, spiritualitas adalah "Cara atau metode guna mendapatkan kinerja pengendalian tertinggi bagi pemanfaatan setiap unsur dari religiositas dalam mencapai tujuannya, yaitu kelimpahan sejati." 20 Secara fenomenologis, spiritualitas dapat berarti suatu perpaduan antara Roh dan kata." ${ }^{21}$ Dapat diartikan bahwa Roh adalah penggerak seseorang untuk dapat bernafas dan bergerak. Spiritual pada dasarnya tidak berkaitan dengan fisik, pikiran maupunn perasaan. Dalam pandangan Kristen, spiritualitas dapat diartikan sebagai sikap hidup berdasarkan firman Tuhan dan tuntunan Roh Allah (Rm. 8:14-16).

Kecerdasan Spiritual (SQ) pada pokoknya adalah sebuah transendensi yaitu transimisi dari wilayanh-wilayah tertentu pada diri individu, yakni dari wilayah material

\footnotetext{
${ }^{17}$ Peter Salim dan Yenny Salim, op.cit s.v. "cerdas".

${ }^{18}$ Ismael Banne Ringgi, Studi Eksplanatori - Konfirmatori Empat Area Kecerdasan di Kalangan Mahasiswa STAKN Toraja Berdasarkan Model Teladan Kehidupan Yusuf dalam Kejadian 37 - 50._(Disertasi STKN Toraja), 180.

${ }^{19}$ Pius Abdillah dan Danu Prasetya, Kamus Lengkap Bahasa Indonesia Masa Kini (Surabaya: Arkola), S.V "spiritual".

${ }^{20}$ Budi Yuwono, SQ Reformation (Jakarta: Gramedia Pustaka Utama, 2010), 8.

${ }^{21}$ Simon Chan, Spiritual Theology (studi sistematis tentang kehidupan Kristen) (Yogyakarta: Yayasan ANDI, 2002), 14.
} 
pada diri menuju kepada spiritual, dari hal jasmanis ke hal spiritual." 22 Danah Zohar dan Ian Marshall mengatakan, "SQ adalah kecerdasan dalam kaitannya dengan pemecahan masalah, kecerdasan spiritual membuat seseorang mampu menghadapi dan memecahkan suatu masalah dengan baik dan benar, dalam konteks yang lebih luas kecerdasan spiritual membuat seseorang memandang orang lain lebih bermakna dibandingkan dengan segala sesuatu. Bertingkahlaku dengan suatu pem ahaman bahwa setiap yang dilakukan adalah sesuatu yang bermakna." ${ }^{23}$ Kecerdasan spiritual adalah bahagian dalam diri manusia yang erat kaitannya denganpengambilan sikap bijaksana diluar kesadaran seseorang, dalam artian hal ini dilakukan tanpa paksaan dan tidak bertindak pura-pura, SQ merupakan kecerdasan sangat bermanfaat dan mendorong dalam kepemenuhan pembangunan diri secara holistik. Kecerdasan Spiritual menempatkan Tuhan yang maha esa sebagai poros kehidupan dan inti dari setiap tindakan. Kecerdasan ini senantiasa memberikan solusi bagi setiap permasalahan yang ada baik itu yang bersifat universal, beragam maupun persamaan." ${ }^{24}$ Kecerdasan spiritual dalam konteks pendidikan nilai dan karakter dalam pendidikan Kristen adalah kemampuan yang ada pada diri setiap manusia yang menjadikannya untuk mempu menganalisis setiap masalah serta mampu menyelesaikan permasalahan tersebut dengan berfokus pada penyelesaian yang berpedoman pada Ajaran Kristus. Berpikir dan bersikap positif, hidup arif dan bijaksana tanpa dipengaruhi oleh keadaan duniawi.

\section{Indikator Kecerdasan Spiritual}

\section{Kasih}

Kasih adalah hal yang sangat urgen dalam kekristenan, kasih merupakan tempat bergantungnya seluruh hukum taurat. Dari kesembilaan buah rohpun diawali dengan kasih. Kasih adalah ajaran utama dan terutama yang diajrakan oleh Tuhan Yesus. Rasul Paulus dengan jelas memberikan suatu arahan dalam 1Korintus 13: 2 bahwa walaupun memiliki segalanya tetapi tidak memiliki kasih maka tidaklah berguna. Matius 22:39 berisi suatu perintah langsung oleh Tuhan Yesus untuk mengasihi, siapakah yang akan dikasihi yakni Allah dan sesama manusia, adapun perintah ini adalah penyingkapan dari hukum taurat dalam Keluaran Pasal 20. Bahkan Matius 5:44 dengan jelas memberikan suatu perintah kepada setiap umat percaya kepada Kristus untuk mengasihi musuh dan orang yang membenci patut untuk di doakan. Pilar hidup orang percaya adalah iman, pengharapan dan kasih, namun yang lebih besar dari semua itu adalah kasih. Kasih adalah penekanan penting dalam ajaran Tuhan Yesus. Bahkan Tuhan sendiri itu adalah kasih "Yohanes 15:9-10. John Haba mengatakan, "Kautamaan dari segala moralitas

\footnotetext{
22Jansen Sinamo, 8 Etos Keguruan (Jabar: IKAPI Jabar, 2012), xxxiii-xxxiv.

${ }^{23}$ Danah Zohar dan Ian Marshall, SQ, Memanfaatkan Kecerdasan Spiritual dalam Berfikir Integralistik dan Holistik untuk Memaknai Kehidupan (Bandung: Mizan, 2001), 135.

24Jansen Sinamo, Sains, Etika dan Keluhuran ( Bandung: Bina Media Informasi, 2002), 121.
} 
kekristenan adalah pengaplikasisan kasih dalam kehidupan. Kasih yang menuntun pada persekutuan dengan Roh. "25 Pada dasarnya dalam seluruh kitab tidak ada yang bertentangan, demikian pula dengan kasih. Kasih adalah penggenapan hukum taurat, setiap pembenaran maupun kebenaran yang ada tidak bertentangan dengan kasih namun suatu kesatuan yang tidak dapat dipisahkan. Aktualisasi kasih sangat didukung oleh suatu kebenaran yang mutlak. Judith Allen Shelly mengatakan, "Harga diri dan martabat didukung oleh perasaan kasih untuk mengakuai martabat dan harga diri seseorang, pun rasa dimiliki mapun memiliki didukung oleh kepemilikan rasa kasih." 26 Rasa saling memiliki diantara seseorang akan membuat dirinya untuk mengasihi dengan sepenuh hati bahkan rela berkorban untuk orang yang dikasihinya, dalam realisasi hukum taurat di Perjanjian baru penekanannya adalah kasih yakni kasih kepada Tuhan dan juga kasih terhadap sesama manusia, aktualisasi ini harus nyata, bagaimana seseorang bisa mengasihi Allah jika tidak memiliki kasih terhadap sesama manusia yang kelihatan. Yesus mengasihi dunia ini sehingga Dia rela mati untuk menebus dosa manusia (Yoh. 3:16), inilah kasih yang sesungguhnya yang rela berkorban tanpa mengharapkan suatu imbalan yang sepatutnya ditiru oleh setiap orang. Oleh karena itu kehidupan anak-anak Tuhan haruslah menggambarkan sikap kasih terhadap sesama secara khusus terhadap Tuhan Allah (Mat. 22:37-40).

Hal yang istimewa dalam ajaran Pendidikan Kristen dan pembeda dari ajaran dalam kurikulum manapun adalah pengimplementasian kasih yakni rasa saling memiliki diantara seseorang yang membuat dirinya untuk mengasihi dengan sepenuh hati, hidup damai dengan orang yang dikasihi bahkan rela berkorban untuk orang yang dikasihinya. Kasih kepada Allah dapat dinyatakan dengan memiliki rasa Takut akan Tuhan.

\section{Takut Akan Tuhan}

Kasih manusia kepada Allah dapat dinyatakan dengan sikap rasa takut manusia kepada Tuhan, takut akan Tuhan" meliputi berbagai aspek berbeda dari hubungan seorang percaya dengan Allah. Takut akan Allah adalah perasaan dan penghargaan atas kekudusan Allah. Takut akan dia sungguh di dasari bahwa Allah itu adalah Allah yang kudus dan suci, oleh karena itu untuk mengbhampiri Allah yang kudus dan suci itu perlu dengan penghormatan yang sungguh. Takut akan Allah merupakan aplikasi dari ketaan dan rasa kagum akan kekudusan Allah. Kekaguman manusia terhadap kekudusanNya membuat manusia penuh rasa segan dan hormat yang sungguh kepada-Nya. Takut akan Allah tidak membuat manusia menjauh dari Allah namun, rasa kekagumana akan karya Allah membuat manusia takut Akan Dia. Segala yang Tuhan kehendaki terjadi maka itulah yang terjadi. Dalam penciptaan Tuhan hanya cukup berfirman dan langit, bumi

25John Haba, Pendidikan Agama Kristen (Jakarta: Universitas Terbuka, 2009), 30.

26Ibid., 91. 
serta segala isinya ada. Kuasa-Nya yang sungguh luar biasa membuat manusia kagum kepada-Nya. Tidak ada yang gagal dalam pandangan Allah. Keyakinan iman dan kepercayaan sungguh kepada Allah merupakan aplikasi takut akan Tuhan. Manusia menaruh iman dan percaya kepada Allah karena adanya rasa Takut akan Dia. Takut akan Tuhan adalah kesadasan bahwa Dia adalah Allah yang cemburu dan marah apabila umatnya tidak melakukan apa yang dikehendaki-Nya. Takut akan Tuhan membuat manusia tidak menduakan Allah karena Dia Allah yang akan sangat marah jika diduakan oleh umatnya, rasa takut akan Tuhan menjadikan indivisu untuk setia kepada Allah dan senantiasa menghormati keberadaan Allah yang kudus. Takut akan Allah adalah siakap memandang Allah sebagai Allah yang begitu geram terhadap dosa, yang tidak segansegan menghukum umat-Nya yang berdosa namun juga sangat mengasihi umat-Nya. "27 Mazmur 112:1 mengatakan, Berbahagialah orang yang takut akan Tuhan yang sangat suka kepada segala perintahNya. Ayat Firman Tuhan ini menyingkapkan bahwa rasa takut kepada Tuhan bukaanlah karena adanya kecaman tetapi karena adanya rasa hormat, dan disertai dengan ketaatan kepada Tuhan dalam melakukan perintah Tuhan. Raja Salomo dalam Amsal 1:7 menguraikan bahwa takut akan Tuhan merupakan permulaan pengetahuan artinya pengetahuan yang sesungguhnya hanya di dalam Tuhan dan di dapatkan jika seseorang hormat dan taat kepada perintah Tuhan. Rasa takut akan Tuhan dilakukan karena kuasaNya yang besar selaku pencipta segala sesuatu dan segala bangsa (Mzm 33:6-9), kuasa Allah yang besar itu menopang segala unsur-unsur ciptaanNya termasuk manusia, serta berkat dari Allah kepada manusia yaitu berkat jasmani dan berkat Rohani.

Keberhasilan kurikulum secara umum diukur dari pencapaian pada aspek kognitif, afektif dan psikomotor. Kurikulum pendidikan Kristen menawarkan hal yang berbeda yaitu keberhasilan kurikulum dalam konteks pendidikan Kristen jika anak takut akan Tuhan yang adalah permulaan pengetahuan hal itu ditunjukkan dengan tindakan seseorang dengan rasa hormat kepada Allah yang membenci dosa dan disertai dengan ketaatan akan segala perintah-Nya.

\section{Jujur}

Jujur menunjuk kepada sikap lurus hati; tidak berbohong, tidak curang." 28 Jujur merupakan suatu tindakan yang dilakukan dan diungkapkan sesuai dengan keadaan yang sesungguhnya terjadi. Jujur mengacu pada sikap polos yang dalam prakteknya tidak bersangkut paut dengan kebohongan, jujur dalam artian selalu menempatkan sesuatu tepat pada tempatnya yang selayak-layaknya sesuai dengan tuntutan dan kebenaran."29 Dalam kaitannya dengan etika, maka kejujuran adalah hal yang harus

${ }^{27}$ Hupriel Hulu, Suluh Siswa 1 (Jakarta: BPK Gunung Mulia, 2000), 14-17.

${ }^{28}$ Peter Salim dan Yenny Salim. Op Cit, s.v "jujur"

${ }^{29}$ Syaful Sagala dan Syawal Gulton, Praktek Etika Pendidikan di Seluruh Wilayan NKRI (Bandung: Alfa Bandung, 2011), 50. 
diutamakan. Sikap jujur adalah hal yang sepertinya pada dunia modern dan semakin canggih ini seolah-olah ditinggalkan. Budaya berbohong senantiasaa mengakar untuk menutupi kesalahan dan untuk kepentingan diri sendiri. Seyogianya, sikap jujur akan membawa pribadi seseorang untuk merasa damai, aman dan tenteram karena tidak dihantui rasa bersalah, serta akan membawa rasa puas pada diri orang lain karena tidak ada hal yang ditutupi. Etika dan moralitas yang tinggi dimulai dengan adanya sikap jujur, kartono menjelaskan, "Pribadi dan moralitas yang tinggi dimulai dari pertanggung jawaban dan kejujuran." ${ }^{30}$ Sikap jujur adalah sikap menempatkan sesuatu sesuai dengan kebenaran yang ada, bertindak tanpa ada manupilasi, menempatkan segala sesuatu pada tempatnya tanpa ada penambahan ataupun pengurangan, bertindak apa adanya dan tidak bersikap curang

\section{Sabar}

William Barclay mengatakan, "semangat Makrothumia ialah sikap tahan dalam menerima setiap perlakuan yang tidak menyenangkan, walaupun pada hal itu menyakitkan namun semangat sabar membuat dirinya mampu untuk bertahan semangat kesabaran membuat individu mampu menghadapi siapa saja, dalam kondisi yang buruk sekalipun dan perlakuan buruk sekalipun, yang disertai dengan sikap tanpa dendam maupun rasa sakit hati“31 Kesabaran (dalam Yunani, hupomone), merupakan salah satu kata yang tidak terdapat dalam buah Roh. Kesabaran dalam hal ini adalah kesabaran yang mengacu kepada suatu keadaan, dimana dalam hal ini kesabaran berkaitan dengan sikap mamopu untuk menderita dalam keadaan apapun (1Tes. 1:3). Tahan menderita (makrothumia) dan kesabaran (hupomone) muncul bersama-sama dalam Kolose 1:11 menuliskan bagaimana kekuatan dari Allah menguatankan setiap orang percaya untuk senantiasa sabar dan tekun dalam menghadapi keadaan yang terjadi. Paulus mengajarkan agar manusia mengejar kesabaran selain keadilan, ibadah, kesetiaan, kasih dan kelembutan karena kesabaran adalah salah satu sifat dari Allah sehingga sebagai manusia Allah, orang percaya pun wajib mengejar semuanya itu. Dalam Mazmur. 86:15, pemazmur mengungkapkan perasaan hatinya kepada Tuhan dengan mendan limpah dengan kasih karunia. Ayat ini menunjukkan bahwa kesabaran dapat dilakukan dengan penuh kasih dan setia. Tuhan Yesus Kristus telah menunjukkan seluruh kesabaran-Nya dengan mengasihani orang yang paling berdosa seperti Paulus, agar mendapat hidup yang kekal (ITim. 1:16) lanjut Efesus 4:2 dikatakan, "Hendaklah kamu selalu sabar tunjukkanlah kasihmu dalam hal saling membantu. Sikap sabar itu termasuk sabar dalam menanggung segala sesuatu, karena sabar adalah bagian dari kasih, I Korintus 13:4, 7 dan buah-buah Roh, Galatia 5:22.

30 Ibid

31William Barclay, Pemahaman Alkitab setiap hari (surat-surat Galatia dan efesus) (Jakarta; BPK Gunung Mulia, 2008), 208. 
Kurikulum berbasis nilai dalam pendidikan Kristen mengacu pada sikap cerdas secara spiritual adalah memiliki sikap panjang sabar terhadap perilaku orang lain maupun sikap sabar terhadap keadaan, kesabaran hanya dapat dilakukan jika hidup penuh rasa kasih dan setia.

\section{Penguasaan Diri}

Mengendalikan atau menguasai diri dapat diartikan sebagai suatu sikap menahan diri terhadap suatu keinginan. Dalam bahasa aslinya penguasaan diri adalah enkrateia yang berarti kekuasaan, kuasa atau penguasaan atas diri sendiri. Sikap penguasaan diri adalah mampu menyangkal diri dari segala sesuatu yang bertentangan dengan kehendak Allah. Tentunya sikap yang bertentangan dengan kehendak Allah adalah sikap duniawi yang senantiasa menggoda manusia untuk melakukannya. Dengan jelas dikatakan oleh Rasul Paulus bahwa hanya ada dua hal, yakni hal duniawi dan hal dari Allah, jika itu tidak sesuai dengan yang diinginkan oleh Allah, maka sudah tentu itu adalah keduniawiaan, keduniawiaan itu berkaitan dengan keinginan daging.

Kedewasaan dibentuk dari sikap pengendalian diri, yakni mampu menguasai diri dan tidak ikut dalam arus keduniawiaan. Sungguh sikap keduniawian snagatlah menggoda dan dalam pandangan manusia itu sangat menyenangkan. Dalam suratnya kepada jemaat di Korintus dalam 2 Korintus 10:5b menjelaskan penguasaan diri dengan menaklukkan diri serta menfokuskan hati dan pikiran dengan mengarahkan kepada Kristua. Penguasaan diri dimulai dengan pikiran yang terarah kepada Allah. Pikiran yang positif dan mengacu pada Allah, itulah yang membuat seseorang untuk menguasai dirinya. Pikiran positif merupakan awal yang tepat untuk tindakan yang tepat. Konsep tentang penguasaan diri dalam Amsal 21:23 yakni dengan memelihara lidah, dengan menjaga lidah dan mulut maka menghindarkan seseorang dari permasalahan. Hal yang sangat penting dalam kaitannya dengan penguasaan diri adalah dengan menjaga mulut dan lidah. Yakobus mengibaratkan lidah seperti api yang dapat menimbulkan bara api dalam hati seseorang karena perkataan yang tidak baik dan benar, lidah adalah bagian terkecil dari anggota tubuh, namun sangat berbahaya dalam Yakobus 3:5 oleh karena itu dalam hal ini penguasaan diri dimulai dari kemampuan untuk menaklukkan lidah yang merupakan bagian terkecil dari anggota tubuh ini. Lanjut dalam pasal 3:9 dikatakan, dengan mulut kita memuji Tuhan Bapa kita, dan dengan lidah kita mengutuk manusia yang diciptakan menurut gambar dan rupa Allah. Lidah dapat digunakan untuk kemuliaan Tuhan dan memberitakan hal-hal yang baik namun dengan lidah pula dapat menjadi petaka. Jadi hendaklah lidah dapat digunakan dengan sebaik mungkin untuk memuji Allah. Penguasaan diri juga ditunjukkan dengan penguasaan terhadap mata. Jadi jika terang yang ada padamu gelap, betapa gelapnya kegelapan itu." (Mat. 6:22-23), selanjutnya penguasaan diri ditunjukkan dalam 1 Tesalonika 4:3-7 mengenai nafsu seks. 
Pengendalian diri atau Penguasaan diri ( Self Regulation ) merupakan satu aspek penting dalam kehidupan seseorang. Penguasaan diri pada dasarnya adalah kemampuan diri untuk mampu membatasi diri untuk tidak melakukan, penguasaan diri adalah penaklukan diri sendiri terhadap sesuatu yang direspon oleh diri sendiri yang datangnya dari liuar diri, dengan demikian penguasaan diri perlu latihan badani dan berproses dari hari kesehari, penguasaan diri bukanlah suatu kemampuan bawaan namun mengacu kepada kemampuan mengolah diri dan menaklukkan diri sesuai dengan kebenaran Firman Tuhan. Orang yang mengizinkan Roh kudus menjadikan dirinya serupa dengan gambaran Kristus akan mengembangkan penguasaan diri dalam setiap bagian kehidupannya."32

Orang yang cerdas secara spiritual sebagai aplikasi dari nilai dan karakter dalam pendidikan Kristen adalah penguasaan diri yakni pengendalian atas diri sendiri dengan mengendalikan pikiran, mata, lidah dan hawa nafsu terhadap hal-hal yang jahat dan tidak berguna, dengan demikian dalam pengendalian diri membutuhkan keterbukaan kepada Roh Kudus untuk menuntun dan menguasai seluruh kehidupan.

\section{KESIMPULAN}

Kurikulum yang dikembangkan dalam pembelajaran Pendidikan Kristen berbasis nilai dan karakter diharapkan mampu menjadikan siswa SMA Negeri di Tana Toraja cerdas secara spiritual oleh karena kecerdasan ini adalah dasar dari segala kecerdasan. Kurikulum dari masa ke masa dikembangkan pada intinya mengacu kepada pengimplementasian nilai dan pengembangan karakter anak sesuai dengan kebutuhan dan tuntutan zaman. Dari hasil penelitian ini penulis memberikan suatu kesimpulan bahwa kurang maksimalnya pengaruh kurikulum berbasis nilai dan karakter menjadikan siswa SMA Negeri di Tana Toraja cerdas secara spiritual dalam menunjukkan sikap kasih, takut akan Tuhan, jujur, sabar dan memiliki penguasaan diri diakibatkan oleh karena pembuatan kurikulum pendidikan agama Kristen yang masih bersifat sekuler kemudian belum mampu dikembangkan menurut kebutuhan kebudayaan dan keadaan lingkungan anak, dengan demikian, pengimplementasian kurikulum tidak merata, serta nilai yang diharapkan bersifat relatif.

Pada konteks pendidikan Kristen, kurikulum bersumber dari Alkitab, dan berlaku secara umum bagi setiap orang disegala tempat, adapun nilai dalam pembentukan karakter dalam kaitannya dengan kecerdasan spiritual ini yang perlu dikembangkan yakni nilai kasih yang merupakan perintah utama Tuhan Allah, kesiapan untuk mendengar dan lambat untuk berkata-kata, nilai kekudusan yakni tidak menajiskan diri dengan berbagai godaan jasmani dan nilai-nilai dari buah Roh Kudus yakni kasih, 204.

\footnotetext{
${ }^{32}$ Antonio Giberto da Silva, Kehidupan yang berkelimpahan (lembaga kursus tertulis Indonesia),
} 
sukacita, damai sejahtera, kesabaran, kemurahaan, kebaikan, kesetiaan, kelemah lembutan dan penguasaan diri.

\section{Referensi}

Abdillah Pius dan Danu Prasetya, Kamus Lengkap Bahasa Indonesia Masa Kini Surabaya: Arkola

Banne Ringgi Ismael, Studi Eksplanatori - Konfirmatori Empat Area Kecerdasan di Kalangan Mahasiswa STAKN Toraja Berdasarkan Model Teladan Kehidupan Yusuf dalam Kejadian 37 - 50._ Disertasi STKN Toraja.

Barclay William, Pemahaman Alkitab setiap hari (surat-surat Galatia dan efesus) Jakarta; BPK Gunung Mulia, 2008.

Chan Simon, Spiritual Theology (studi sistematis tentang kehidupan Kristen) Yogyakarta: Yayasan ANDI, 2002.

Cut Zahri Harun, Manajemen Pendidikan Karakter

Fitri Wahyuni, Kurikulum Dari Masa ke Masa (Telaah Atas Pentahapan Kurikulum

Pendidikan Di Indonesia), (Al-Adabiah: Jurnal Kebudayaan dan Keagamaan: vol 10 no 2 tahun 2015), 233-237.

Giberto da Silva Antonio, Kehidupan yang berkelimpahan lembaga kursus tertulis Indonesia.

Haba John, Pendidikan Agama Kristen Jakarta: Universitas Terbuka, 2009.

Hamid Hasan Said dkk. Pengembangan Pendidikan Budaya dan Karakter Bangsa Jakarta:

Kemdiknas Badan Penelitian dan Pengembangan Pusat kurikulum, 2010.

Hulu Hupriel, Suluh Siswa 1 Jakarta: BPK Gunung Mulia, 2000.

Koesema Doni, Pendidikan Karakter (strategi mendidik anak di zaman global) Jakarta: GRASINDO, 2007.

May Rauli Simamora dkk, Penanaman Nilai-Nilai Kristiani Bagi Ketahanan Keluarga Di

Era Disrupsi Regula Fidei: Jurnal Pendidikan Agama Kristen Volume 5, Nomor 1, Maret 2020

Prayitno \&belferik M, Pendidikan Karakter dalam Pembangunan Bangsa Jakarta:

Grasindo, 2011.

Rifai, "Pendidikan Kristen Dalam Membangun Karakter Remaja Di Sekolah Menengah, (Antusias-Jurnal Teologi dan Pelayanan 2, no. 2 (2012).

Rusman, Managemen Kurikulum (Seri managemen sekolah bermutu) Jakarta: PT Raja grafindo Persada, 2009.

Sagala Syaful dan Gulton Syawal, Praktek Etika Pendidikan di Seluruh Wilayah NKRI Bandung: Alfa Bandung, 2011.

Salim Peter dan Yenni Salim, Kamus Bahasa Indonesia Kontemporer Jakarta: Modern English Press, 1995. 
Santy Sahartian, Pemahaman Guru Pendidikan Agama Kristen Tentang II Timotius 3:10 Terhadap Peningkatan Kecerdasan Spiritual Anak Didik (JURNAL FIDEI Vol.1 No.2 (December 2018): ISSN: 2621-8151(Print) ISSN: 2621-8135(online).

Siahaan Harls Evan Rianto, "Hikmat Sebagai Implikasi Pendidikan Kristiani: Refleksi 1 Raja-Raja 3:1-15," (DUNAMIS: Jurnal Penelitian Teologi dan Pendidikan Kristiani 1 , no. 1 (2016).

Sidjabat Samuel Binsen, "Kerangka Kurikulum Pendidikan Agama Kristen Berbasis Karakter Di Perguruan Tinggi Character-Based Christian Religious Education Curriculum Framework in Higher Education, (Jurnal Jaffray 17, no. 1 (2019) Sinamo Jansen, 8 Etos Keguruan Jabar: IKAPI Jabar, 2012.

Sinamo Jansen, Sains, Etika dan Keluhuran Bandung: Bina Media Informasi, 2002. Soewitomo Putri Agustin, "Menstimulasi Kualitas Kehidupan Rohani Dalam Meningkatkan Kemandirian Belajar Mahasiswa: Studi Refleksi Daniel 6:1-4, DUNAMIS: Jurnal Penelitian Teologi dan Pendidikan Kristiani 1, no. 22017. St. Sularto, Masyarakat Warga dan Pergulatan Demokrasi Jakarta: Pustaka Nasional, 2001.

Suprayitno Adi, Pendidikan Karakter di era minenial Yogyakarta: Deepublish, 2020. Yuwono Budi, SQ Reformation Jakarta: Gramedia Pustaka Utama, 2010.

Zohar Danah dan Marshall Ian, SQ, Memanfaatkan Kecerdasan Spiritual dalam Berfikir Integralistik dan Holistik untuk Memaknai Kehidupan Bandung: Mizan, 2001. 